\title{
Desain dan Kasus Pembajakan Karya Intelektual di Indonesia
}

\author{
Ferry Darmawan dan Saefuddin
}

\begin{abstract}
Design piracy, though considered as serious problems, is often overlooked. This phenomenon commonly found in Third World countries. The government have been have been employing many ways to reduce piracy, such as adopting Intellectual Property Rights. But the effort to combat piracy was challenged by some parties which benefited from such activities. Piracy, in micro perspective, eliminates fair competition and creates unfair competition. The culture of piracy also harassed and submerged the role of law. Law enforcement toward Intellectual Property Rights is a must. The challenge is how to awaken members of society toward the importance of Intellectual Property Rights.
\end{abstract}

Kata kunci: Hak atas Kekayaan Intelektual, pembajakan, desain.

\section{Menyoal HaKI dan Pembajakan Karya Intelektual}

Kegiatan pembajakan karya cipta merupakan suatu hal yang sangat meresahkan masyarakat, khususnya bagi para pencipta/produksi penciptaan dan juga masyarakat pengguna yang benar-benar ingin mendapatkan benda/barang yang orisinal, bukan bajakan. Pembajakan karya ini banyak sekali terjadi seperti di bidang usaha rekaman maupun artis yang ada di Indonesia saat mereka hendak menjual hasil karyanya ke pasar. Bukan hal aneh, pembajakan karya ini begitu merajalela, nyaris tidak ada yang mampu membendungnya. Produk bajakan banyak sekali kita temukan, mulai dari $C D, V C D, D V D$, buku, hingga program komputer, diperjualbelikan secara bebas. Bahkan menurut Bussiness Software Alliance (BSA), 88 persen pasar peranti lunak (software) di Indonesia diisi oleh barang bajakan (http:/ /kompas.com/kompas-cetak/0507/02/fokus/ 1858858.htm, diakses 21 September 2006). Data lain menyebutkan bahwa sepanjang tahun 1995, kawasan Asia telah mencuri pendapatan AS lebih dari 6 milyar dolar. Indonesia tercatat "mencuri" 98 persen untuk produk film hiburan (motion pictures) dan perangkat lunak aplikasi bisnis (bussiness application), dengan nilai hampir 132 juta dolar AS. Secara keseluruhan, Indonesia telah "mencuri" pendapatan AS lebih dari 217,9 juta dolar AS dari pembajakan produk film, software aplikasi bisnis, rekaman musik, software home entertaintment, dan buku. $^{1}$

Namun, tidak bisa dipungkiri, keberadaan 
barang bajakan memberikan nilai lebih tersendiri bagi masyarakat. Berkat barang bajakan tersebut, sebuah karya baru yang berkualitas dapat dinikmati oleh seluruh lapisan masyarakat. Hal ini karena harga versi bajakan jauh di bawah harga aslinya. Dapat kita lihat misalnya, jika sebuah harga VCD orisinal seharga 50.000 rupiah, dengan versi bajakannya hanya dihargai 10.000 rupiah saja. Atau, sebuah program komputer (software) yang dikeluarkan oleh produsen dengan harga ratusan ribu rupiah, di pasar bajakan dapat kita beli dengan harga 7.500 hingga 50.000 rupiah saja.

Contoh lain, untuk menjalankan komputer rakitan seharga 3 jutaan, harus mengeluarkan dana tambahan hingga 2,5 juta rupiah lebih bila kita menggunakan software asli, dengan gambaran $O S$ Windows XP seharga AS\$78 plus MS Office seharga AS\$170. Melalui ilustrasi tersebut, maka wajar saja produk hasil bajakan merupakan primadona di masyarakat, dengan alasan klasik, karena harga yang asli jauh lebih mahal.

Menurut sejarah, sebenarnya masalah pembajakan bukan hal baru. Menjelang tahun 1960, terjadi kasus plagiat yang sangat menghebohkan. Seorang ulama termashur, Hamka, dianggap oleh lawan politiknya telah melakukan penjiplakan karya, di mana roman Tenggelamnya Kapal Van der Wijk (1938) merupakan saduran dari karya Alphonse Karr, Sous les Tilleuls (1808-1890). ${ }^{2}$ Sesungguhnya, pada akhir abad ke-19, beratus roman bahasa Belanda atau Cina telah disadur ke dalam bahasa Melayu tanpa ada celaan apa pun pada penyadurnya.

Hal yang sedikit berbeda dikatakan oleh Abd. Moqsith Ghazali. Menurutnya, kalau kita mengikuti perkembangan tradisi Islam klasik, para ulama yang menulis beribu-ribu judul buku tidak pernah memiliki hak cipta. Sebagai contoh, kita bisa melihat Al Ghazali. Ratusan buku karyanya beredar di pasar, tapi ahli warisnya tidak pernah mendapatkan royalti atas karya tersebut. Bahkan, tidak ada hak cipta bagi Al Ghazali sehingga masyarakat bebas mengopinya.

Di kalangan intelektual Muslim, juga terdapat tradisi untuk tidak mengomersialkan ilmu, karena hal tersebut dapat mengurangi kadar keikhlasan.
Meski demikian, secara sederhana pembajakan dalam Islam itu identik dengan ghasab (mengambil barang tanpa sepengetahuan pemiliknya) atau sariqah (pencurian) (http://www.islam emansipatoris.com/artikel.php?id=37, diakses 21 September 2006).

Kita juga harus jujur bahwa kita harus memberikan apresiasi terhadap karya-karya intelektual tersebut. Penghargaan yang layak patut diberikan kepada para pemegang hak cipta tersebut guna menumbuhkan produktivitas dalam negeri. Bisa dibayangkan jika sebuah karya cipta dihargai rendah, tentu para musisi atau seniman mungkin menjadi tidak produktif.

Kasus lain, adalah sebuah karya desain grafis dari desainer Thalia Kamarga pada avocadolite.com yang tak luput dari pembajakan. Kasus ini terungkap ketika desainer tersebut dalam sebuah situs internet mengeluh karena karyanya dijiplak. Karya desain grafisnya seperti dapat kita lihat pada gambar-gambar di bawah ini.

Perhatikan, pada Gambar 1 adalah gambar asli, sedangkan gambar 2 dan 3 adalah produk desain bajakan dari gambar 1 (http://blog.godote.com/ 2005/09/pembajakan-karya.html, diakses 22 Agustus 2006).

Pembajakan desain memang tak jarang dianggap sepi. Tak heran jika kasus pembajakan ini yang muncul ke permukaan nyaris tidak ada. Padahal, sebuah desain sangat mudah ditiru. Misalnya dalam pameran, khususnya UKM, umumnya akan memamerkan produk belum didaftarkan. Seseorang dengan hanya memotret produk itu, kemudian membuatnya dengan desain yang sama dan mendaftarkan atas nama dirinya, maka dia mendapatkan hak atas desain produk tersebut. Secara tidak langsung, siapa pun bisa mendapatkan hak desain industri yang seharusnya milik orang lain secara legal.

Berkaitan dengan fenomena tersebut, berbagai cara telah dilakukan oleh pemerintah dan pihak-pihak yang terkait untuk memberantas pembajakan Hak atas Kekayaan Intelektual (HaKI) ini, yaitu mulai dari sweeping terhadap barangbarang bajakan yang beredar di pasar, hingga mensahkan UU Hak Cipta No.19 tahun 2002, yang 
Gambar 1: Karya orisinal oleh Thalia Kamarga of avocadolite.com

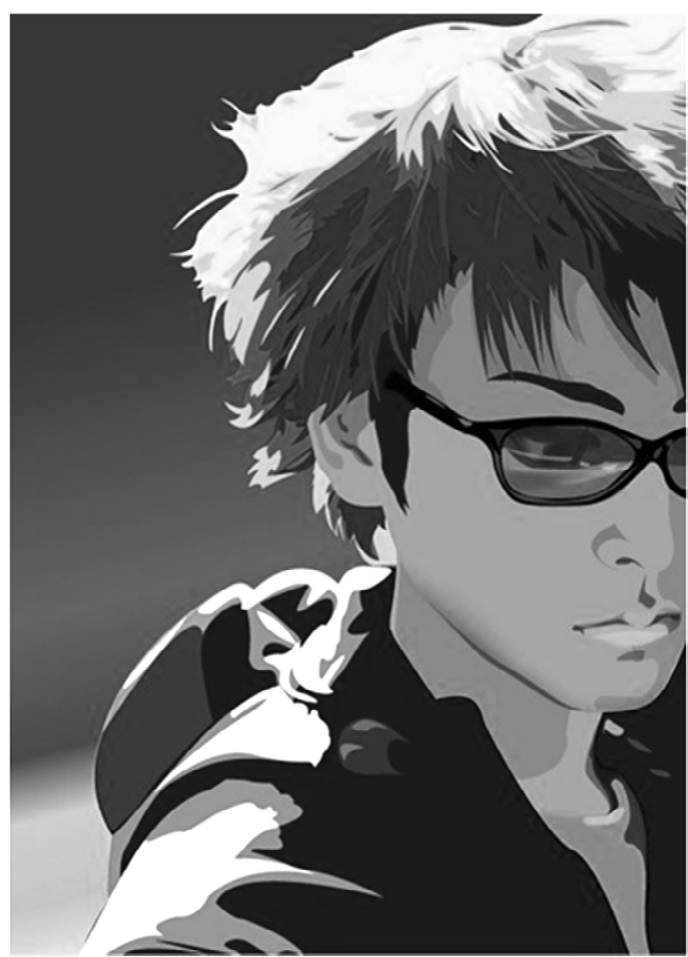

sudah diberlakukan sejak 29 Juli 2003, dan membawa kemajuan baru dalam perlindungan hak tersebut, yang meliputi perlindungan terhadap buku, program komputer, pamflet, perwajahan karya tulis yang diterbitkan, dan semua hasil karya tulis lain, ceramah, kuliah, pidato, lagu atau musik dengan atau tanpa teks, drama, tari, koreografi, pewayangan dan pantomim, seni rupa dalam segala bentuk, arsitektur, peta, seni batik, fotografi, sinematografi, terjemahan, tafsir, saduran, bunga rampai, data base, dan karya lain dari hasil pengalihwujudan.

Banyak terdapat pasal-pasal yang sebenarnya cukup memberatkan para pelaku pembajakan HaKI ini. Misalnya pada pasal 72, ayat (2), disebutkan, "Barang siapa dengan sengaja menyiarkan, mengedarkan, atau menjual kepada umum suatu ciptaan atau barang hasil pelanggaran Hak Cipta atau Hak Terkait, sebagaimana dimaksud dalam ayat (1) dipidana dengan pidana penjara paling lama 5
Gambar 2: Gambar grafis yang dijiplak untuk gambar sampul sebuah buku.

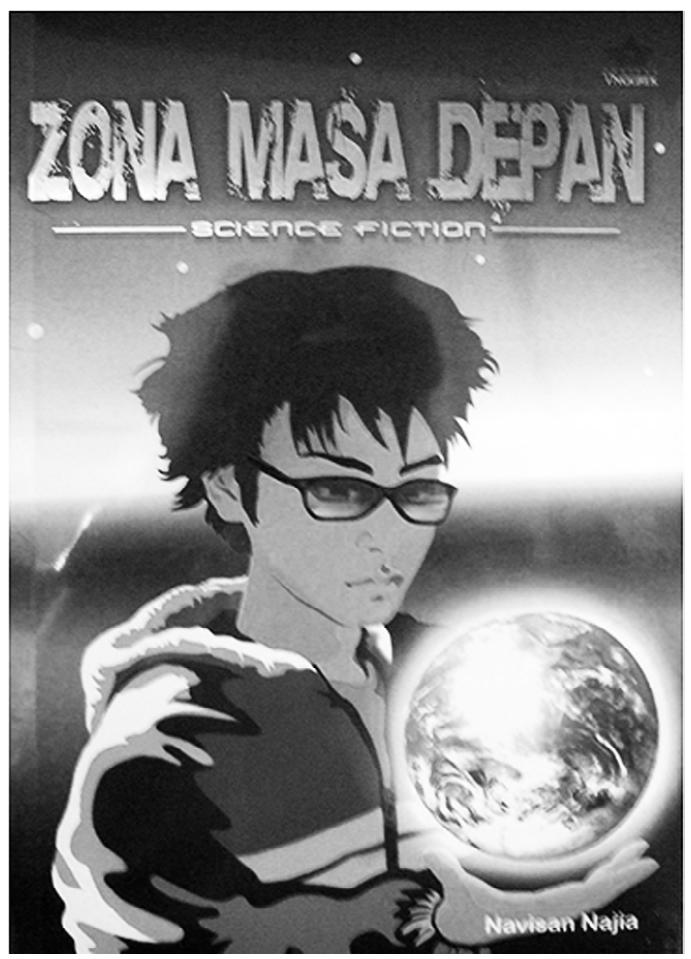

tahun dan/ atau denda paling banyak Rp. 500.000.000,00 (lima ratus juta rupiah)". Sedangkan dalam ayat (3) UUHC disebutkan bahwa barang

\section{Gambar 3: Gambar yang sama untuk desain "neon box" (papan reklame) sebuah toko.}

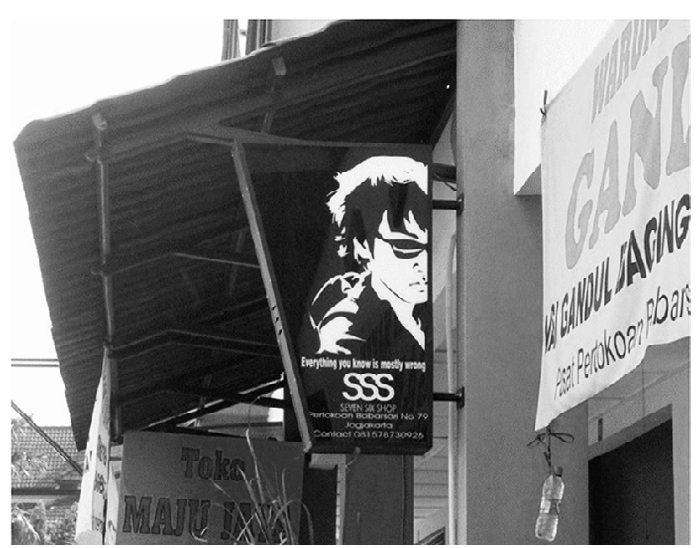


siapa dengan sengaja tanpa hak memperbanyak penggunaan untuk kepentingan komersial suatu program komputer dipidana paling lama 5 tahun penjara dan atau denda 500 juta rupiah. Namun, pemberlakuan UUHC ini bukan berarti menyurutkan langkah para permbajak. Memang, pada awal UU ini diberlakukan, hampir di seluruh sudut penjualan barang bajakan, seperti VCD, CD, Software, pedagang dan produk yang dijual seolah menghilang dari pasar. Namun, hal ini tidak berlangsung lama. Kenyataannya sekarang pembajakan karya cipta masih terus marak dan subur.

Menurut Ranti Fauza Mayana ${ }^{3}$, melalui pembajakan orang-orang yang terlibat telah diuntungkan. Tetapi di sisi lain, sekaligus telah merusak sendi-sendi hukum dan kehidupan masyarakat itu sendiri. Budaya pembajakan di satu sisi telah mengancam kreativitas masyarakat pencipta dan di sisi lain, secara makro, telah mengganggu rasa keadilan masyarakat banyak, karena budaya ini telah menghilangkan persaingan sehat (fair competition) dan melahirkan makin maraknya persaingan tidak jujur (unfair competition). Sedang dari sudut filosofis yuridis, budaya pembajakan justru telah melecehkan dan menenggelamkan peran hukum, sehingga tujuan hukum akan semakin sulit tercapai.

Ditegaskan pula oleh Ranti, penegakan hukum di bidang hak cipta sangat dipengaruhi oleh peran objektivitas hakim dalam memutuskan perkaraperkara hak cipta. Hakim harus secara konsisten menegakkan hukum dalam melindungi pencipta berdasarkan prinsip-prinsip Undang-undang Hak Cipta (UUHC) dan prinsip-prinsip Trade Related Aspects of Intellectual Property Rights-World Trade Organization (TRIPs-WTO).

Kasus-kasus pelanggaran hak cipta merupakan salah satu penghambat serius tercapainya tujuan UUHC. Dalam berbagai kasus pelanggaran hak cipta, tampak jelas bahwa keadilan bagi pencipta tidak tercapai dan penegakan hukum terhadap pihak-pihak yang melakukan pembajakan terhadap suatu karya cipta tersebut juga tidak tercapai. Misalnya, kasus penyanyi dangdut A. Rafiq yang melaporkan produser Raam Punjabi karena dianggap menggunakan lagu-lagunya dalam sebuah sinetron yang dibuat rumah produksi Punjabi tersebut, di mana pengadilan negeri memenangkan Punjabi dalam kasus ini.

Kendala lain, sebenarnya juga terletak pada masyarakat Indonesia sendiri. Masyarakat kita tahu tentang perlindungan hak cipta, tapi tidak mau melaksanakan ketentuan itu. Dalam UUHC, memang disebutkan bahwa pembeli dan penikmat karya cipta tidak termasuk pelanggar hak cipta selama terbatas digunakan untuk diri sendiri. Akan tetapi, tindakan para penikmat karya bajakan ini justru menyuburkan pelanggaran-pelanggaran hak cipta.

Masih menurut Ranti, fenomena lain yang patut untuk disimak adalah benarkah penerapan UUHC di Indonesia merupakan kesadaran penuh pemerintah Indonesia untuk melindungi HaKI atau hanya karena desakan ekonomi global (WTO). Dalam laporan Kantor Perwakilan Perdagangan AS - United States Trade Representative (USTR), menyebutkan bahwa Indonesia termasuk daftar negara yang sangat perlu diawasi (priority watch list) dan terancam sanksi dagang berupa blokade ekspor ke AS, karena dituduh "melakukan praktik dagang yang tidak fair".

Carlos Corriea, seorang peneliti Third World Network, mengatakan bahwa perjanjian yang berkaitan dengan masalah HaKI, sebetulnya bukan hanya bermaksud mengurangi pembajakan seperti yang disebutkan dalam laporan USTR, tapi sekaligus merupakan kebijakan yang melakukan proteksi atas teknologi dan memperkuat pembagian kerja internasional baru. Negeri industri maju menjadi penghasil temuan, sementara negeri berkembang menjadi pasar dari produk dan jasa yang dihasilkan. Sementara, sulit menunjukkan seberapa jauh masyarakat menikmati "transfer teknologi” yang konon mengiringi investasi asing ke sini, kelemahan dan kekurangan dari aturan main itu sudah mulai tampak.

Sejumlah aktivis LSM, seperti Indah Suksmaningsih dari YLKI, dan Hira Jhamtani dari Konphalindo, berulangkali menggugat kesadaran negara peserta WTO yang semakin diikat dalam posisi tidak setara secara ekonomi, teknologi, dan 
kesejahteraan. Mereka menunjukkan bahwa keanekaragaman hayati (biodiversity) akan terancam dengan keluarnya aturan tentang paten. Dengan modal kuat dan teknologi penelitian canggih, negara maju bisa mencaplok habitat binatang atau tumbuhan khusus melalui paten. Penjarahan sudah berlangsung cukup lama. Tahun 1998, misalnya, perusahaan Rice Tec dari AS mengajukan hak milik intelektual atas padi asal India yang selama bertahun-tahun menjadi milik bersama. Rumah mode Yyes St Laurent mengklaim paten atas ilang-ilang, sejenis bunga dari Filipina. Lebih jauh dikatakan bahwa rezim HaKI internasional telah menciptakan jurang antara negeri maju dan negeri berkembang seperti Indonesia.

\section{Pengertian dan Ruang Lingkup HaKI}

HaKI awalnya mencakup dua konsep besar, yakni hak cipta (copyright) dan hak paten, yang diatur secara terpisah. Istilah "intelektual" dalam HaKI berarti hak cipta melindungi hasil kecerdasan, pikiran, dan ungkapan atau renungan manusia yang menjelma dalam bentuk buku, lagu, atau film. Sementara, hak paten mencakup temuan dan teknologi, kerja yang dikerahkan untuk membuat barang baru, mulai dari traktor, obat-obatan, sampai alat pembuka kaleng yang menggunakan listrik.

Asumsinya hak cipta selalu berkenaan dengan uang, karena untuk merancang, membuat, memperbanyak, dan memasarkan sebuah karya cipta diperlukan uang dan para pemegang hak cipta tentu mengharapkan uang yang ditanamkan akan kembali. Sedangkan menurut Ronald V. Bettig (1992), konsep HaKI baru mulai dibicarakan setelah ditemukannya mesin cetak dan merebaknya kapitalisme dalam dunia tulis menulis. Sebelumnya pengetahuan atau cerita milik umum dan tidak diketahui siapa yang pertama mengungkapkan. Artinya, konsep hak cipta lekat dengan kekuasaan modal dan dalam konteks penerbitan, misalnya, menjadi jelas bahwa yang lebih berkepentingan akan hak itu adalah penerbit yang mengeruk keuntungan daripada pengarang yang mencipta. ${ }^{4}$

Menurut Lindsey (2000), pengertian HaKI pada umumnya berhubungan dengan perlindungan penerapan ide dan informasi yang memiliki nilai komersial. HaKI adalah kekayaan pribadi yang dapat dimiliki dan diperlakukan sama dengan bentuk-bentuk kekayaan lainnya.

Sebagian besar kekayaan intelektual dapat dan bisa diperjualbelikan seperti sebuah buku, HaKI juga dapat disewakan selama kurun waktu tertentu di mana pihak penyewa membayar sejumlah uang kepada pihak yang menyewakan hak tersebut untuk menggunakan kekayaan intelektual tersebut. Perjanjan tersebut disebut lisensi.

Berkaitan dengan ruang lingkup perlindungan HaKI, ada banyak hal yang dapat dilindungi oleh HaKI, yaitu : termasuk novel, karya seni, fotografi, lembaran musik, rekaman suara, film, software dan hardware komputer, situs internet, desain untuk barang-barang yang diproduksi secara masal, makhluk hidup hasil rekayasa genetika, obatobatan baru, rahasia dagang, pengetahuan teknik, karakter serta merek.

\subsection{Ruang Lingkup Hukum HaKI}

Dijelaskan Lindsey (2000) bahwa hukum HaKI tidak diperluas terhadap setiap situasi dimana seseorang yang melakukan usaha atau sumber daya ke dalam suatu yang melibatkan pengeluaran budi, pengetahuan, keahlian atau tenaga. Berdasarkan hukum di Indonesia dan UU di banyak negara, ciptaan dan invensi hanya akan dilindungi jika ciptaan dan invensi tersebut memenuhi syaratsyarat tertentu yang telah diatur UU. Sebagai contoh, invensi di bidang ilmiah/scientifik discoveries tidaklah dilindungi. Paten hanya berlaku terhadap sebuah proses dan produk serta pengembangan proses atau produk, dan bukan pada teori ilmu pengetahuan atau penemuan (discovery) dari beberapa makhluk hidup atau unsur kimia tertentu yang sudah ada sebelumnya secara alami. Contoh lain disebutkan sebuah teori yang rumit dan betul-betul ilmiah dapat dipakai untuk membantu pembuatan pesawat terbang agar bersifat lebih aerodinamis, tidak dapat dipatenkan meskipun perkembangan teori tersebut memakan waktu yang lama serta biaya yang tidak sedikit. 


\subsection{Permasalahan Benda Berwujud dan Tidak Berwujud dalam HaKI}

Ditinjau dari cara perwujudannya, HaKI sebenarnya berbeda dengan objek yang berwujud lainnya. Sebagai contoh, hak cipta dalam sebuah lukisan adalah kekayaan yang terpisah dari kepemilikan kanvas lukisannya. Jika Anda membeli sebuah buku, Anda memiliki buku tersebut secara fisik, tetapi bukan Hak Cipta yang ada di dalam buku yang Anda beli tersebut. Kebanyakan rezim HaKi modern tidak sesuai untuk memberikan perlindungan terhadap bentuk-bentuk warisan budaya yang tidak berwujud yang sudah tidak rahasia lagi. Misalnya, hak cipta mensyaratkan identifikasi dari pengarang tertentu, pelestarian karya ke dalam bentuk nyata, dan hanya menyediakan perlindungan bagi klaim individu dari pada kolektif. Oleh karena itu, karya-karya pedesaan yang bersifat tradisional yang tidak memiliki karakteristik seperti tersebut di atas, tidak dapat dilindungi

\subsection{Cabang Utama HaKI}

Cabang utama HaKI terdiri dari hak cipta, paten, desain, merek, rahasia dagang, tata letak sirkuit terpadu dan varietas tanaman, rekayasa genetika, internet dan domain names, pendaftaran, dan ekploitasi/pemanfaatan.

\section{Desain dalam Konteks HaKI}

Seperti disebutkan di atas, desain sebagai salah satu dari sekian banyak dari cabang utama HaKI. Dalam wilayah HaKI, desain berhubungan dengan penampakan secara visual dari produkproduk komersial. Desain biasanya tidak melindungi fungsi dari suatu produk, melainkan semata-mata melindungi penampilan luarnya. Desain orisinal dari produk-produk komersial dilindungi setelah desain tersebut didaftarkan.

Ada permasalahan yang telah mengacaukan banyak pembentuk undang-undang di seluruh dunia adalah berkaitan dengan tumpang tindihnya antara hak cipta dengan desain, karena kedua rezim tersebut melindungi karya-karya artistik.

Desain adalah suatu kreasi tentang bentuk, konfigurasi, atau komposisi garis atau warna, atau gabungan dari padanya yang berbentuk 2D atau pun 3D, yang memberikan kesan estetis dan dapat diwujudkan dalam pola 2D atau 3D serta dapat dipakai untuk menghasilkan suatu produk, barang, komoditas industri, atau kerajinan tangan.

Hak desain diberikan untuk desain yang baru. Desain yang dianggap baru apabila tanggal penerimaan desain tersebut tidak sama dengan pengungkapan yang telah ada sebelumnya.

\subsection{Jangka Waktu Perlindungan}

Jangka waktu terhadap hak desain diberikan untuk jangka waktu 10 tahun, terhitung sejak tanggal penerimaan.

\subsection{Pendaftaran}

Seperti cabang-cabang HaKI lainnya (kecuali Hak Cipta dan Rahasia dagang), UU mensyaratkan adanya pendaftaran sebelum desain tersebut memperoleh perlindungan hukum. Pendaftaran dilakukan di kantor HaKI, dan untuk memproses permohonan pendaftaran tersebut diadakan pemeriksaan terlebih dahulu oleh para petugas di kantor HaKI.

\section{Hubungan Tumpang Tindih antara Hak Cipta dan Desain}

Menurut Lindsey (2002), masalah yang membingungkan para ahli HaKI dan perancang UU di seluruh dunia adalah berkaitan dengan hubungan saling tumpang tindih antar hak cipta dengan desain. Hubungan ini muncul karena desain (suatu cetak biru dari penampilan produk tertentu) biasanya juga merupakan karya seni yang dapat dilindungi hakcipta. Berdasarkan ketentuan UU Hak Cipta, jika karya seni tersebut dipakai sebagai cetak biru untuk pembuatan suatu produk, maka pemegang hak cipta juga mempunyai hak cipta atas produk tersebut.

Barang kali hal ini lebih mudah dijelaskan dengan mengambil contoh sederhana berikut ini. Seorang mendesain sebuah kursi pada sehelai kertas. Jika desain tersebut bersifat baru, pendesain tersebut berhak mendaftarkan karyanya sebagai 
desain. Karya tersebut juga dapat dianggap sebagai karya seni menurut UU Hak Cipta. Jika pendesain tersebut membuat kursi dengan menggunakan desain tadi, pendesain juga memiliki hak cipta atas kursi (hal ini disebut desain yang terhubung). Keadaan ini muncul oleh karena pendesain sebagai pemilik hak cipta, mempunyai hak eksklusif untuk membuat karya tersebut dalam bentuk 3D.

Dibandingkan dengan UU Desain, UU Hak Cipta banyak memberikan manfaat bagi seseorang. Misalnya, pendaftaran tidak diperlukan dan masa perlindungan Hak Cipta berlangsung lebih lama.UU desain memang diarahkan untuk melindungi barang-barang yang diproduksi secara massal.

\section{Undang-undang HaKI dan Kondisi Bangsa Indonesia}

Perlindungan desain memberikan hak monopoli kepada pemilik desain atas bentuk, konfigurasi, pola atau ornamentasi tertentu dari sebuah desain. Dengan demikian, hukum desain hanya melindungi penampilan bentuk terluar dari suatu produk. UU Desain tidak melindungi aspek fungsional dari sebuah desain, seperti cara pembuatan produk, cara kerja, atau aspek keselamatannya. Pembuatan, pengoperasian dan ciri-ciri barang tertentu dilindungi oleh hukum paten.

Namun, tampaknya pemerintah tidak serius menanggapi permasalahan HaKI tersebut. Hingga kini, niat pemerintah untuk benar-benar memberantas aksi pembajakan dan pelanggaran HaKI memang belum terlihat serius. Padahal, payung hukumnya sudah jelas, yakni dengan UU tentang HaKI. Namun praktik penegakan hukumnya masih sangat lemah dan sanksi hukum bagi pembajak dan pelanggar hak cipta masih rendah, sehingga para pembajak tidak dibuat jera dengan hukuman yang diterimanya.

Kasus-kasus pembajakan karya cipta cenderung marak di belahan dunia ketiga, yakni negara berkembang, negara miskin dan berpenduduk banyak. Himpitan ekonomi, seperti di Indonesia, setelah badai krisis moneter pada 1998, tidak juga kunjung reda menyebabkan tingkat daya beli lapisan masyarakat semakin jauh terhadap barang kebutuhan sehari-harinya, sehingga orang kebanyakan menggunakan barang-barang yang sesuai dengan daya belinya.

Produk-produk desain sudah menjadi kebutuhan dan alat bantu kegiatan sehari-hari pada hampir semua lapisan masyarakat, dari ibu rumah tangga, pelajar, mahasiswa, karyawan maupun profesional. Produk-produk tersebut diperoleh dengan pengeluaran biaya yang terjangkau dengan tidak mempedulikan produk asli atau bajakan dan ini sudah menjadi hal lumrah, sehingga ketika diberlakukan penegakan hukum HaKI, tampak terjadi kekalutan luar biasa di seluruh lapisan masyarakat dan bisnis. Rental-rental film mengambil jalan aman dengan menutup sementara usahanya, kantor-kantor - baik kantor pemerintah maupun swasta - waswas manakala datang petugas yang tiba-tiba memeriksa komputernya.

Kemudian muncul pertanyaan, apakah benar selama ini sudah mendapatkan barang yang murah dan lumrah menggunakan barang bajakan? Dari uraian di bagian awal tulisan ini terdapat data yang menunjukkan bahwa sebenarnya kata murah (bahkan sangat-sangat murah) muncul ketika semata-mata membandingkan harga produk asli dengan produk hasil bajakan. Misalnya, dalam satu contoh kasus, harga untuk satu program komputer hasil bajakan Rp. 10.000, dengan program komputer asli kira-kira Rp. 3.000.000. Tetapi, harga perangkat lunak asli tersebut menjadi tidak masuk akal apabila diterapkan pada rata-rata pelajar di seluruh Indonesia, atau bahkan sebagian besar lapisan masyarakat yang sudah menggunakan teknologi informasi untuk membantu kegiatan sehari-harinya. Dengan demikian, akan muncul kategori-kategori barang-barang mewah tergadap barang-barang yang sebelumnya merupakan barang kebutuhan sehari-hari.

Dengan kondisi bangsa yang terhimpit ekonominya, akan muncul dilema yang sangat terasa dengan adanya penegakan UU Hak Cipta, bahwa yang justru menjadi korban adalah bangsa sendiri. Krisis moneter yang berkepanjangan 
menyebabkan menurunnya daya beli masyarakat. Faktor ini telah memengaruhi perilaku konsumen untuk mencari/membeli barang yang terjangkau (bias bermakna: murah), sehingga barang bajakan seakan-akan telah menyelamatkan kehidupannya.

\section{Penutup}

Teknologi dan perkembangan informasi berkembang pesat dalam berbagai bentuk media membanjiri masyarakat dengan bermunculannya informasi produk-produk baru dalam bentuk iklan. Membanjirnya iklan produk-produk baru ini turut andil dalam membentuk masyarakat konsumtif, sehingga meraka berusaha mendapatkan produkproduk baru dengan harga yang terjangkau. Gayung bersambut, perilaku konsumtifmasyarakat disambut dengan peluang bisnis yang menggiurkan oleh pihak-pihak tertentu yang menyediakan barang-barang bajakan. Kondisi ini berjalan terus dengan tetap dibiarkannya toko/ penjual barang-barang bajakan. Pemegang kebijakan dan pelaku penegak HaKI hanya bertindak secara temporer saja, sehingga penyedia barang bajakan masih menjamur seperti sedia kala.

Mengingat kurangnya perhatian dan keseriusan pemerintah dalam mengangani kasuskasus yang berhubungan dengan pembajakan karya cipta, praktek-praktek pembajakan dan penggunaan produk-produk ilegal masih banyak terjadi. Di sisi lain dari kelompok para peduli HaKI yang terkumpul dalam komunitas seniman (pencipta karya seni) melalukan gerakan antipembajakan karya seni sudah digemakan di kotakota besar Indonesia sejak jauh hari sebelumnya. Para seniman tidak hanya membagi-bagikan stiker, tapi juga pemasangan spanduk di jalan-jalan protokol. Isinya, antara lain, "Dengan Hari Musik Indonesia Budayakan Rasa Malu Membeli Produk Bajakan", "Pecinta Musik Indonesia Menyatakan Perang terhadap Pembajakan Karya Cipta Seniman Musik Indpnesia" dan "Jangan Beli Produk Bajakan!”.

Gerakan anti-pembajakan itu terus digemakan hampir pada tiap kesempatan, baik dalam diskusi, seminar, maupun pembentukan organisasi antipembajakan. Hingga dalam sebuah diskusi anti- pembajakan di Jakarta, para seniman musik mendeklarasikan Suara Perjuangan Artis Indonesia (Spaind). Melalui wadah ini, mereka bersatu untuk melawan pembajakan karya seni. Bahkan, grup musik Slank, membuat secara khusus album bertitel Bajakan!(http://www.republika.co.id/ koran_detail.asp?id=204939\& kat_id=306 \&kat_id1=\&kat_id2, diakses 22 September 2006)

$\overline{\mathrm{D}} \mathrm{i}$ Australia masalah menangani tumpang tindih antara hak cipta dengan desain diselesaikan dengan cara sebagai berikut. Jika sebuah gambar digunakan untuk membuat sebuah barang yang berbentuk 3D dan barang tersebut diproduksi masal, perlindungan hak cipta dianggap hilang. Pembuatan sebuah barang dianggap sebagai diproduksi massal jika barang tersebut dibuat sebanyak 50 buah atau lebih. Berdasarkan ketentuan ini, seseorang lebih memilih mencari perlindungan desain dari pada mengandalkan UU Hak Cipta.

Penegakan hukum terhadap pelanggaran UU hak cipta masih mengalami kendala meskipun telah terbitnya undang-undang terbaru, yakni UU Hak Cipta No.19Tahun 2002, yang berupakan hasil revisi undang-undang sebelumnya. Dalam banyak kasus pelanggaran hak cipta akan terbentur dilemadilema dalam penegakan HaKI, meliputi konsepsi HaKI dan persepsinya, political will pemerintah, kualitas pengaturan, "dilema pasar", para penegakan hukum makro, transparansi proses pengadilan, instansi penegak hukum, dan HaKI yang terus berkembang.

Kembali pada awalnya masalah, HaKI tidak dapat dilepaskan dari adanya hubungan antara negara industri/maju dan negara berkembang, khususnya karena adanya unintended transfer of wealth dari negara industri ke negara berkembang.

Pada sisi lain, penegakan HaKI dianggap akan menghambat transfer of knowledge. Dengan payung UU, penguasaan keahlian hanya akan dimonopoli pihak-pihak tertentu saja. Sebagaimana pernah menjadi keputusan pemerintah untuk keluar dari "Berne Convention". Tujuan keluar dari konvensi ini adalah bersifat strategis, yakni agar dapat mudah melakukan transfer ilmu pengetahuan dan teknologi dari luar ke dalam negeri dengan 
cara menyadur, menerjemahkan buku-buku, meniru hasil ciptaan5. Dengan demikian, kebiasaan meniru atau menjiplak sebagian dari warisan keputusan politik strategis masa lalu.

Justifikasi yang paling mendasar untuk HaKI adalah bahwa sesorang yang telah mengeluarkan usaha ke dalam penciptaan memiliki sebuah hak alami untuk memiliki dan mengontrol apa yang telah mereka ciptakan. Pendekatan ini menekankan pada kejujuran dan keadilan. Dilihat sebagai perbuatan yang tidak jujur dan tidak adil jika mencuri usaha seseorang tanpa mendapatkan mendapatkan terlebih dahulu persetujuannya.

Penegakan hukum HaKI pada dasarnya mengandung arti bagaimana menjadikan masyarakat sadar HaKI. Penegakan tersebut bisa dilakukan melalui dua cara:

Pertama, orang perorang berhak menggugat pelanggar ke pengadilan atau lembaga yang berfungsi sebagai pengadilan atas dasar pelanggaran HaKI. Upaya hukuman yang dapat diberikan antara lain ganti kerugian, pemunahan barang pelanggaran, penetapan sementara, dan lain-lain.

Kedua, yang bisa dipakai untuk memaksa orang supaya menaati HaKI adalah melalui negara. Di banyak negara, negara berhak menghukum orang yang melanggar peraturan perundangundangan dengan sanksi pidana. Akan tetapi, sanksi pidana tersebut jarang dipakai di negara yang menganut sistem hukum Anglo Saxon.

Sebagai kelompok seorang pencipta/ desainer berusaha untuk mendaftarkan karyanya bilamana memang telah memenuhi ketentuan HaKI serta menyosialisasikan peran positif HaKI kepada seluruh pencipta/desain industri, dan masyarakat luas terhadap dampak penyelewengannya.

\section{Catatan Akhir}

1 Hasil kajian Wakil Presiden International Intelectual Property Alliance (IIPA) Amerika Serikat, Steven J. Metalitz. Lepas dari keabsahan hasil kajian tersebut, namun temuan ini patut menjadi sorotan semua pihak, khususnya di Indonesia. (sumber: Kompas Online)
Karya Alphonse Karr ini diterjemahkan dalam bahasa Arab oleh Mustafa Luthfi Al Manfaluthi dengan judul Madjulin (Madeleine). Karya inilah yang menjadi sumber Hamka mengarang Tenggelamnya Kapal van der Wijk, dengan banyak saduran tentunya (ceritanya terjadi di Minangkabau). Pada terbitan ke-7, oleh lawan politik Hamka diperkarakan sebagai kasus plagiat. Polemik memuncak, kemudian teks Manfaluthi di terjemahkan ke dalam bahasa Indonesia dengan judul Magdalena tahun 1964, agar pembaca dapat menilai sendiri. (Sumber: Nusa Jawa: Silang Budaya, Jilid 1, Denys Lombard, 2000).

3 Doktor Ilmu Hukum Unpad dengan kajian Desain Industri (sumber: Pikiran Rakyat Online)

4 Uraian diberikan oleh Ignatius Haryanto, jurnalis dan wakil direktur Lembaga Studi Pers dan Pembangunan (LSPP) Jakarta, dalam http://mkb.kerjabudaya.org/ mkb-092002/mkb-rubrik-092002/esai-092002.htm, diakses 22 September 2006.

\section{Daftar Pustaka}

\section{A. Buku}

Lombard, Denys, 2000, Nusa Jawa: Silang Budaya, Jilid 1.

Lindsey, Tim. Dkk. 2002. Hak kekayaan Intelektual, Suatu Pengantar, PT. Alumni, Bandung.

Ronald V. Bettig, 1992. Critical Perspectives on History and Philosophy of Copyright, Critical Studies in Mass Communication.

Rakhmat, Jalaluddin, 1993, Metode Penelitian Komunikasi, Rosda Karya, Bandung.

Sachari, Agus, 2005, Pengantar Metodologi Penelitian Budaya Rupa, Erlangga, Jakarta.

\section{B. Internet}

http://www.pikiran-rakyat.com

http://kompas.com/kompas-cetak/0507/02/fokus/ 1858858.htm.

http://www.islamemansipatoris.com/ artikel.php?id=37. 
http://mkb.kerjabudaya.org/mkb-092002/mkbrubrik-092002/esai-092002.htm.

http://www.republika.co.id/koran_detail.asp?id=2 04939\&kat_id=306\&kat_id1=\&kat_id2.

http://www.iptek.net.id/ind/patent/ index.php?id=72.

http://blog.godote.com/2005/09/pembajakan- http://encyclopedia.laborlawtalk.com/Pirate karya.html. http://www.republika.co.id/koran_detail.asp?id=20 4939\&kat_id=306\&kat_id1=\&kat_id2.

http://www.pemantauperadilan.com/detil/ detil.php?id=148\&tipe=kolom.

http://www.sinarharapan.co.id/ekonomi/industri/ 2003/0910/ind1.html. 